\title{
Personality Model Representation using ONTOLOGY
}

\author{
VidACEK-HAINS, V.; LOVRENCIC, S. \& KiRINIC, V.
}

Abstract: Ontologies are among the most extensively researched areas in computer science, consequently numerous ontologies have already been developed for various domains. As a result, ontology evaluation and their use in the concept of Semantic Web have now become a major research concerns. However, the use of ontologies in certain domains, for example in the field of personality psychology is still in the development.

Therefore, the aim of this paper is to explore the possible application of ontologies in some of the existing multidimensional personality models. In particular, to explore whether such an approach contributes to the clarity and visibility of a specific personality model and/or improves the effective unification of different types of information. In this case, the Costa and McCrae five factor personality model was used and the ontology was developed using the Protégé tool.

Key words: personality, five factor model, ontology development, ontology evaluation, Protégé
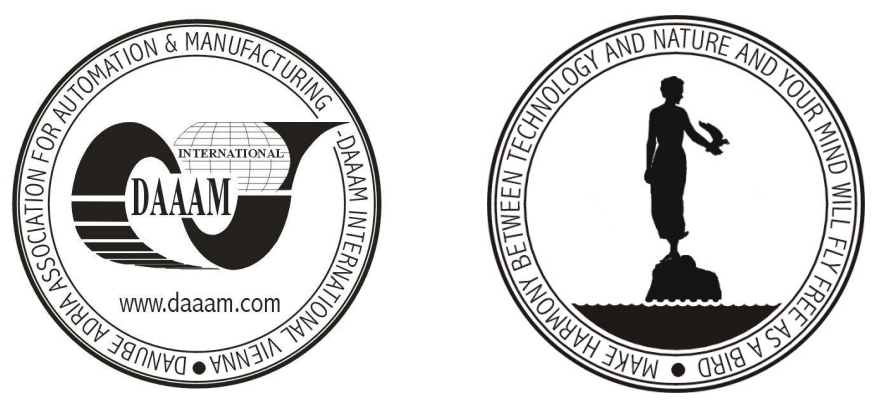

Authors' data: Ph.D. Vidacek-Hains, V[ioleta]; Ph.D. Lovrencic, S[andra]; Ph.D. Kirinic, V[alentina], University of Zagreb, Faculty of Organization and Informatics Varaždin, Pavlinska 2, HR-42000 Varaždin, Croatia, vvidacek@foi.hr, sandra.lovrencic@foi.hr, valentina.kirinic@foi.hr

This Publication has to be referred as: Vidacek-Hains, V.; Lovrencic, S. \& Kirinic, V. (2007). Personality Model Representation using Ontology, Chapter 37 in DAAAM International Scientific Book 2007, B. Katalinic (Ed.), Published by DAAAM International, ISBN 3-901509-60-7, ISSN 1726-9687, Vienna, Austria

DOI: $10.2507 /$ daaam.scibook.2007.37 